\title{
PENINGKATAN HASIL BELJAR IPA MELALUI METODE RESITASI PADA SISWA KELAS V SD INPRES BORONG JAMBU II KOTA MAKASSAR
}

\author{
Ina Febriyanti1), Satriawati2), (ayati²), Bellona Mardhatillah Sabillah ${ }^{4}$ ) \\ ${ }^{1}$ PGSD, Universiras Megarezky \\ Inanungsu@gmail.com \\ ${ }^{2}$ PGSD, Univesitas Megarezky \\ satriawati.01@gmail.com \\ ${ }^{3}$ PGSD, Universitas Megarezky \\ cayatijepot@gmail.com \\ ${ }^{4}$ PGSD, Universitas Megarezky \\ bellona.sabillah@gmail.com
}

\begin{abstract}
Ina febriyanti, 2021. An improving science Learning Outcomes through the Recitation Method for Class V students of the Inpres Borong Jambu II Elementary School in Makassar. Supervised by Satriawati and Cayati
\end{abstract}

This study aims to improve student learning outcomes in science subjects through the recitation method in class V of the Inpres Borong Jambu II Elementary School in Makassar. The approach used is a quantitative approach with classroom action research. The subjects of this study were 26 students consisting of 13 male students and 13 female students. The research instruments were student observation sheets, teacher observation sheets, tests, documentation, and data analysis techniques processed and interpreted.

The results showed that student learning outcomes through the recitation method in the first cycle obtained an average value of $66.6 \%$ on the more minor criteria. While in the second cycle, there was an increase with an average value of $84.4 \%$ on the outstanding criteria. The presentation of teacher activities in the first cycle of the first meeting was 1.92 on the sufficient criteria. The second met sufficient criteria with a score of 2.3 meeting III good criteria with a value of 2.7. in comparison, the second cycle of the first meeting was on good criteria with a value of 3.0, and the second meeting with very good criteria with a value of 3.69. meeting III with very good criteria with a score of 3.96. while the presentation of student activities in the first cycle of the first meeting with a score of 1.8 in the average category and the second meeting with a value of 2.00 in the average category. Meeting III with a score of 2.7 in the good category. While the second cycle of the first meeting with a score of 2,07 in the good category and the second meeting with a value of 3.64 in the very good category. Meeting III with a score of 3.92 and very good criteria. This study concludes that using the recitation method can improve science learning outcomes for fifth-grade students at Inpres Borong Jambu II Elementary School in Makassar

\section{Keywords: Recitation Method, Science Learning Outcomes}

Abstrak. Ina Febriyanti, 2021 Peningkatan hasil belajar IPA melalui metode resitasi pada siswa kelas V SD Inpres Borong Jambu II Kota Makassar. Dibimbing oleh Satriawati, S.Pd., M.Pd dan Cayati, S.Pd., M.Pd.

Penelitian ini bertujuan untuk meningkatkan hasil belajar siswa pada mata pelajaran IPA melalui metode resitasi di kelas V SD Inpres Borong Jambu II Kota Makassar. 
Pendekatan yang digunakan adalah pendekatan kuantitatif dengan penelitian tindakan kelas (PTK). Subjek penelitian ini yaitu 26 orang siswa, siswa laki-laki 13, siswa perempuan 13. Instrument penelitian yang dilakukan adalah lembar obsevasi, tes, dokumentasi.

Hasil penelitian menunjukkan bahwa hasil belajar siswa melalui metode resitasi pada siklus I diperoleh nilai rata-rata 66,6\% dengan kriteria kurang. Sedangkan pada siklus II mengalami peningkatan dengan nilai rata-rata $84,4 \%$ dengan kriteria sangat baik dan presentasi aktivitas guru pada siklus I pertemuan I 1,92 kriteria cukup dan pertemuan II kriteria cukup 2,3 dan untuk pertemun III kriteria cukup 2,7 sedangkan siklus II pertemuan I 3,00 dengan kriteria baik dan pertemuan II 3,69 dengan kriteria sangat baik dan pertemuan III 3,96 dengan kriteria sangat baik dan presentasi aktivitas siswa siklus I pertemuan I 1,8 dengan kriteria cukup dan pertemuan II 2,00 dengan kriteria cukup pada pertemuan III 2,7 dengan kriteria baik sedangkan pada siklus II pertemuan I 2,7 dengan kriteria baik dan pertemuan II 3,64 dengan kriteria sangat baik dan pada pertemuan III 3,92 dengan kriteria sangat baik. Kesimpulan dari penelitian ini adalah dengan menggunakan metode resitasi dapat meningkatkan hasil belajar siswa pada mata pelajaran IPA kelas $V$ di SD Inpres Borong Jambu II Kota Makassar.

\section{Kata kunci: Metode Resitasi, Hasil Belajar IPA}

\section{PENDAHULUAN}

Kemajuan suatu bangsa dapat dilihat dari kualitas pendidikan dalam suatu negara. Hal tersebut sejalan dengan pendapat UU RI No 20/2003 bab II pasal 3 (Duratul yattimah, 2017: 3)

"Pendidikan nasional berfungsi mengembangkan kemampuan dan membentuk watak serta peradaban bangsa yang bermartabat dalam rangka mencerdaskan kehidupan bangsa, bertujuan untuk berkembangnya potensi peserta didik agar menjadi manusia yang beriman dan bertakwa kepada Tuhan Yang maha Esa, berakhlak mulia, sehat, berilmu, cakap, kreatif, mandiri, dan menjadi warga negara yang demokratis serta bertanggung jawab.

Pemerintah Indonesia telah melakukan berbagai upaya untuk meningkatkan kualitas pendidikan. Upaya tersebut adalah dengan melakukan penyempurnaan kurikulum dari tahun ke tahun. Penyempurnaan tersebut dimulai dari kurikulum 1994 menjadi kurikulum berbasis kompetensi (KBK), kemudian kurikulum KBK disempurnakan lagi menjadi kurikulum tingkat satuan pendidikan (KTSP) dan kemudian disempurnakan lagi menjadi kurikulum 2013 yang berlaku hingga sekarang. Demikian disempurnakannya kurikulum tersebut diharapkan kualitas pendidikan dapat tercapai secara optimal.

Perubahan kurikulum tersebut, guru memiliki peranan langsung dalam mengelola proses pembelajaran di dalam kelas. Guru sebagai pendidik, pembimbing, mediator, fasilitator, dan evaluator hendaknya memberikan sesuatu yang dapat membantu peserta didik dalam meningkatkan hasil belajar khusunya pada mata pelajaran IPA

Mata pelajaran IPA merupakan pengetahuan yang mempelajari tentang keadan dan kejadian alam secara sistematis dimana IPA dapat mengembangkan pengetahuan dan konsep-konsep IPA yang bermanfaat dan dapat diterapkan dalam kehidupan sehari-hari (Felma Cahyani Sombou, 2019: 3)

Salah satu faktor yang dapat menunjang keterlaksaan pembelajaran secara efektif adalah dengan penggunaan metode pembelajaran dalam hal ini metode Resitasi adalah salah satu metode pembelajaran yang mendorong siswa untuk ikut aktif dalam belajar. Metode Resitasi diharapkan dapat melatih siswa dalam menyelesaikan masalah soal secara individu 
maupun secara berkelompok disesuaikan dengan kondisi yang ada, pembelajarannya menarik dan mendorong siswa untuk terjun kedalamnya, serta siswa lebih semangat belajar (Ayu Anggraini, 2020: 3)

Tetapi realitas yang ada sekarang banyak kita jumpai siswa yang mengeluh tentang kesulitan belajar dalam mengikuti pembelajaran IPA. Kesulitan ini sering kita jumpai pada saat proses belajar mengajar berlangsung, rendahnya hasil belajar siswa karena kurangnya semangat belajar siswa. Dalam satu kelas hanya ada beberapa siswa yang merespon, menyerap dan bahkan mengerjakan soal-soal latihan. Salah satu penyebabnya adalah cara penyajian belajar dan suasana pembelajaran kurang menarik dan menyenangkan (Ayu Anggriani, 2020: 4)

Berdasarkan hasil observasi awal pada tanggal 27 Januari 2021 bahwa nilai dalam proses pembelajaran IPA khususnya di kelas V SD Inpres Borong Jambu II Kota Makassar lebih banyak mendapat nilai dibawah 75 . Rendahnya hasil belajar IPA di pengaruhi oleh dua faktor, yaitu faktor guru dan faktor siswa. Dimana guru kurang menggunakan metode pembelajaran yang kreatif dan inovatif dalam pembelajaran dan lebih berfokus pada penggunaan buku cetak, sehingga siswa kurang menguasai pembeajaran IPA tersebut.

Demikianlah penulis tertarik untuk melakukan penelitian yang berjudul "Peningkatan Hasil Belajar IPA Melalui Metode Resitasi Pada Siswa Kelas V SD Inpres Borong Jambu II Kota Makassar"

\section{METODE}

Penelitian ini merupakan pendekatan kuantitatif. Pendekatan kuantitatif, yaitu penelitian yang berdasarkan pada angka, seperti menghitung hasil evaluasi siswa dalam pembelajaran. (Sugiyono, 2013:37) Jenis penelitian yang digunakan adalah yaitu penelitian tindakan kelas (PTK) aksi yang berulang-ulang untuk memperbaiki proses belajar mengajar dikelas. Hal ini sebagaimana yang diungkapkan oleh kemmis dan tagart menyatakan bahwa: Proses penelitian rindakan ialah sebuah siklus atau proses daur ulang yang terdiri dari empat aspek fundamental, diawali dari aspek mengembangkan perencanaan, lalu melakukan tindakan sesuai dengan rencana, observasi/pengamatan terhadap tindakan, dan diakhiri dengan melakukan refleksi.

Langkah-langkah tindakan yang dilalui merupakan kerja yang berulang (siklus) sehingga diperoleh pembelajaran yang dapat meningkatkan pemahaman siswa terhadap IPA pada siswa kelas V SD Inpres Borong Jambu II Kota Makassar kelas dikatakan belajar jika terjadi perubahan dalam dirinya yang meliputi aspek kognitif, efekif, dan psikomotor.

Berdasarkan pemahaman terhadap tindakan sebagaimana yang telah dipaparkan diatas bahwa secara sederhana PTK dapat diartikan sebagai penelitian tindakan kelas (action research) yang dilakukan untuk memperbaiki kualitas proses dan hasil belajar siswa.

Penelitian ini dilaksanakan untuk meningkatkan hasil belajar siswa dalam pembelajaran IPA dengan penerapan metode resitasi pada pelaksanaannya, penelitian ini dilaksanakan secara kolaborasi antara peneliti dengan guru. Dalam hal ini peneliti berkolaborasi dengan guru dengan tujuan agar lebih mudah dan teliti dalam kegiatan observasi tersebut.

Fokus Penelitian, Penelitian ini dilakukan siswa kelas V SD Inpres Borong Jambu II Kota Makassar berfokus pada dua aspek yaitu: Hasil belajar IPA adalah hasil belajar siswa dalam pembelajaran IPA dengan menggunakan metode resitasi atau disebut juga dengan metode pemberian tugas merupakan metode yang mengharuskan para siswa membuat suatu resume mengenai materi yang sudah disampaikan oleh pengajar.

(Jusmawati et al. 2021) Sehingga, sebaiknya guru menggunakan metode yang tepat menunjang kegiatan belajar, sehingga dapat dijadikan sebagai alat yang efektif untuk 
mencapai tujuan pengajaran. Setting Penelitian tindakan keas dilaksanakan di SD Inpres Borong Jambu II Kota Makassar, tentang peningkatan Hasil Belajar IPA melalui metode resitasi.Waktu PenelitianPenelitian tindakan kelas ini dilaksanakan di kelas V pada semester ganjil di SD Inpres Borong Jambu II Kota Makassar.

Subjek penelitian ini adalah siswa kelas V SD SD Inpres Borong Jambu II Kota Makassar dengan jumlah siswa 26 siswa, dimana jumlah siswa laki-laki 13 siswa dan jumlah siswa perempuan 13 siswa.

Dalam penelitian Tindakan kelas dalam penelitian tindakan kelas ini menggunakan model tindakan menurut Kemmis dan Taggart yaitu rancangan penelitian berdaur ulang (siklus) yang mencakup: (1) tahap perencanaan, (2) tahap pelaksanaan tindakan, (3) tahap observasi dan (4) tahap refleksi. Adapun skema dari model penelitian ini, yaitu sebagai berikut:

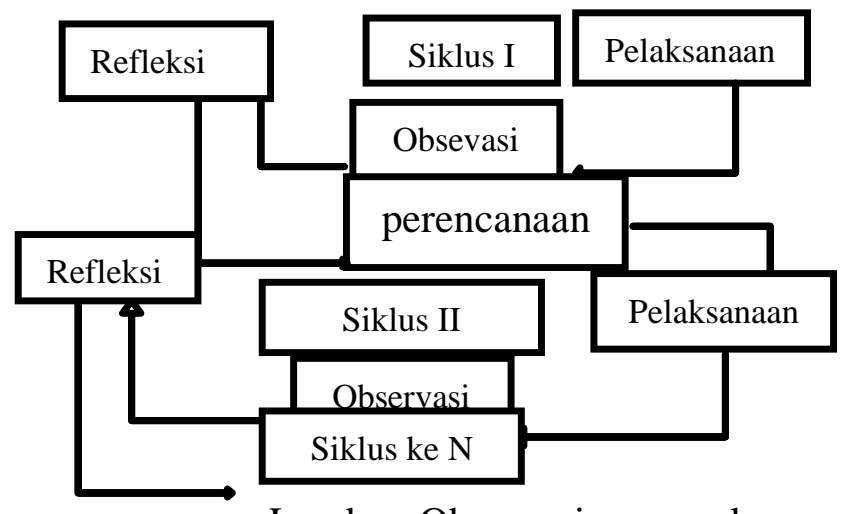

Lembar Observasi merupakan catatan yang menggambarkan tingkat aktivitas siswa dalam proses pembelajaran secara daring, aktivitas siswa dikatakan berhasil jika mencapai skor 75 sudah mencapai kriteria yang telah sitentukan. Teknik pengumpulan data yang digunakan dalam penelitian ini adalah observasi dan tes. Data diambil dari hasil catatan atau obervasi penelitian terhadap siswa selama pembelajaran berlangsung.

Sedangkan untuk mengumpulkan data hasil belajar siswa, dilakukan tes yang diberikan pada setiap siklusnya.Indikator keberhasilan dalam penelitian tindakan kelas ini dinyatakan berhasil apabila adanya peningkatan hasil belajar disetiap siklusnya. Penelitian ini dinyatakan behasil jika $80 \%$ siswa mancapai nilai 75 sesuai dengan nilai KKM yang ditetapkan di sekolah adalah 75 pada pelajaran IPA

\section{HASIL DAN PEMBAHASAN}

\section{Hasil}

Penelitian dilaksanakan di SD Inpres Borong Jambu II Kota Makassar yang perupakan salah satu lembaga pendidikan yang terletak di Kacamatan manggala. Mempunyai 6 ruangan kelas untuk kegiatan belajar mengajar, 1 ruangan kepala sekolah, 1 ruangan guru, 1 ruangan perpustakaan. Subjek penelitian ini adalah siswa kelas V yang berjumlah 26 siswa, terdiri dari 13 siswa laki-laki dan 13 siswa perempuan. SD Inpre Borong Jambu II Kota Makassar dengan system pembagian waktu belajar dari 07:30 - 12:15 WITA di SD Inpres Borong Jambu II Kota Makassar.

\section{Pelaksanaan siklus I}

Pelaksanaan penelitian dilakukan selama empat kali dalam setiap siklus dengan durasi 3x35 menit. Pertemuan I pada siklus 1 dilaksanakan pada hari selasa, 27 Juli 2021 pukul 7:30-09:30, sedangkan pertemuan 2 dilaksanakan pada hari rabu, 28 Agustus 2020 pukul 07:30-09:30 sedangkan pertemuan ke 3 di laksanakan 39 Juli 2021 pukul 07:30- 09:30 
dengan jumlah siswa 26 siswa. Dengan menggunakan metode resitasi untuk meningkatkan hasil belajar siswa pada mata pelajaran IPA kelas V SD Inpres Borong Jambu II. Pada pertemuan pertama,kedua dan ketiga kegiatan awal sebelum memulai pembelajaran terlebih dahulu guru menjelaskan langka langkah pembelajaran yang dilaksanakan dan menyiapkan perangkat seperti berikut :

1) Rencana pelaksanaan Pembelajaran (RPP) dengan menggunakan metode resitasi.

2) Buku pembelajaran tema 1 Organ gerak manusia dan hewan

3) Lembar observasi untuk mengetahui aktivitas siswa dan guru pada saat proses belajar mengajar

4) Soal evaluasi

Peneliti memulai pembelajaran dengan menggunakan media WhattApp dengan doa bersama pada kegiatan aperesepsi yaitu apersepsi guru menyampaikan tujuan pembelajaran. Kemudian peneliti menyampaikan materi pembelajaran berupa video pembelajaran.

Setelah materi dijelaskan, siswa diberikan penjelasan oleh peneliti untuk menyimak materi yang telah di sajikan yaitu organ gerak manusia dan hewan. Otot adalah jaringan yang ada didalam tubuh manusia, berupa alat gerak aktif yang menggerakan tulang sehingga menyebabkan suatu organisme atau individu dapat bergerak. Fungsi otot pada manusia adalah:

1. Menjalankan dan melaksanakan kerja contohnya berjalan, mengangkat, dan memegang,

2. Mengerakkan jantung,

3. Mengalirkan darah yang terdiri atas zat-zat yaitu nutrisi, oksigen, dan Lainnya.

Setelah materi dijelaskan peneliti diberi kesempatan kepada siswa untuk menanyakan materi yang belum jelas. Selanjutya peneliti memberikan tugas evaluasi yang berbubungan dengan materi yang telah di berikan sebelumnya.

Diakhir pembelajaran peneliti memberikan penguatan tentang materi dan tugas yang telah dikerjakan serta memberi motivasi kepada siswa untuk belajar lebih rajin dalam belajar. Peneliti juga melakukan evaluasi untuk melihat tingkat pencapaian hasil belajar siswa. Pengukuran hasil belajar siswa dilakukan dengan mengerjakan soal-soal berupa essay sebanyak 10 butir soal kepada siswa. Siswa mengerjakan soal evaluasi secara individu. Saat siswa sedang mengerjakan soal, Setelah hasil evaluasi dkerjakan dan dikumpulkan, guru memberi penguatan kepada siswa agar lebih rajin belajar dirumah sepaya menjadi anak kyang pandai dan bisa dalam segala hal.

Kemudian guru menutup pembelajaran dan memberi salam. Selanjutnya, guru mengoreksi hail pekerjaan siswa. Dari hasil tes didapat data yang berupa angka-angka mengenai jumlah yang diperoleh siswa.

Hasil yang diperoleh di atas merupakan hasil pengamatan yang dilakukan observer selama kegiatan belajar berlangsung secara online. Hasil observasi pertemuan ketiga terlihat jumlah siswa yang sudah memiliki peningkatan dalam proses belajar mengajar dengan jumlah skor 2,7 atau dalam kategori baik.

\section{Hasil belajar siklus I}

Hasil belajar dapat diketahui dari hasil evaluasi akhir siklus dari materi-materi yang telah dipelajari pada siklus I. nilai rata-rata kelas yang diperoleh keseluruhan siswa pada evaluasi siklus I mencapai 66,6\% dengan nilai tertinggi 85 dan nilai terendah 40. Adapun nilai yang diperoleh siswa pada siklus I dapat disajikan pada tabel 4.3 di bawah ini :

\section{Tabel 4.3 hasil belajar siswa siklus I}




\begin{tabular}{lllcc} 
No & Nilai & kategori & Frekuensi & Peresentase \\
\hline 1. & $<60$ & Sangat Kurang & 5 & $16 \%$ \\
2. $\quad 65-69$ & Kurang & 6 & $24 \%$ \\
3. $\quad 75-79$ & Cukup & 10 & $40 \%$ \\
4. $\quad 85-89$ & Baik & 2 & $8 \%$ \\
5. $\quad 95-100$ & Sangat baik & 3 & $12 \%$ \\
Jumlah & & $\mathbf{2 6}$ & $\mathbf{1 0 0 \%}$ \\
Nilai rata-rata hasil belajar IPA siklus I & $\mathbf{6 6 , 6 \%}$
\end{tabular}

\section{Lampiran 92-93}

Berdasarkan tabel tersebut dapat diketahui hasil belajar siswa dalam kategori sangat baik ada 5 siswa dengan peresentase 12\%, kategori baik ada 2 siswa dengan presentasi $8 \%$, kategori cukup ada 10 siswa dengan presentasi 40\%, kategori kurang ada 6 dengan presentasi $24 \%$, dan kategori sangat kurang ada 4 siswa dengan presentasi $16 \%$. Hasil belajar pada siklus I menunjukkan nilai rata-rata $66,6 \%$ siswa belum mencapai KKM. Hasil tersebut mengindentifikasi penerapan metode resitasi belum berhasil karena belum memenuhi kriteria keberhasilan sebesar $80 \%$ dari keseluruhan siswa telah mencapai KKM.

Karena sebelumnya siswa telah terbiasa pasif dalam menerima materi pengajaran. Selain itu masih terdapat siswa yang kurang aktif saat pembelajaran berlangsung dan siswa yang masih bingung dengan pembelajaran dan dalam mengerjakan soal latihan. Maka perlu dilanjutkan pada siklus II dengan memperhatikan aspek-aspek di atas. Hal ini terjadi karena apabila peneliti memberikan pertanyaan dengan menggunakan motode resitasi.

Hasil yang diperoleh siswa pada siklus I dikategorikan masih di bawah standar ketuntasan belajar karena belummencapai indikator keberhasilan yang telah ditetapkan yakni $80 \%$ yang memperoleh nilai $\geq 75$. Sehingga peneliti merasa perlu mengadakan tindakan siklus II sebagai perbaikan dari siklus I. Hasil observasi, evaluasi, dan refleksi pelaksanaan tindakan siklus I belum mencapai target indikator keberhasilan yang ditentukan oleh peneliti sehingga peneliti ingin melanjutkan tindakan pada siklus II. kelemahan dan kekurangan yang ada pada siklus I akan diperbaiki pada siklus II, begitupun keberhasilan-keberhasilan pada siklus I akan dipertahankan dan ditingkatkan di siklus II.

\section{Pelaksanaan siklus II}

Seperti halnya pada siklus I, siklus II dilakukan dalam 3 kali pertemuan 1 pada tanggal 5 Agustus 2021 dan pertemuan 2 pada tanggal 7 Agustus 2021 pada pertemuan 3 pada tanggal 9 Agustus 2021 Kelas yang digunakan dalam penelitian tindakan kelas ini sama dengan siklus I, yaitu kelas V dengan jumlah siswa 26, sedangkan yang hadir pada saat pembelajaran siklus II berlangsung hadir semua dengan total 26 siswa. Pembelajaran IPA yang dilakukan guru sesuai dengan rencana pelaksanaan pembelajaran (RPP) yang disusun sebelum penelitian dilaksanakan. Sedangkan peneliti bersama observer melakukan observasi. Materi yang diberikan adalah materi IPA.

Kegiatan diawali dengan salam pembukaan doa bersama dan dilanjutkan dengan melakukan apersepsi, selanjutnya guru penyampaikan tujuan yang akan dipelajari adalah manusia dan manfaatnya guru menyapiakan materi pembelajaran berupa video pembelajaran, guru memberikan arahan kepada siswa untuk menyimak materi dengan saksama setelah bebera saat guru membagikan soal evalusi yang sesuai dengan materi. Selama kegiatan berlangsung guru mengarahkan siswa untuk bertanya apabila ada yang kurang dipahami, guru benar-benar memperhatikan bahwa siswa mengerjakan tugas yang diberikan. 
Pada pertemuan selanjutnya hari sabtu, Agustus 2021, guru mengingatkan kembali kepada siswa mengenai materi yang telah dipelajari pada pertemuan sebelumnya. Setelah peneliti menjelaskan materi siswa diminta untuk menanyakan hal-hal yang belum dipahami dari penjelasan peneliti.

Pada akhir pembelajaran peneliti bersama dengan siswa membuat kesimpulan materi yang telah dipelajari hari ini. Siklus II diakhiri dengan kegiatan evaluasi dengan memberikan soal evaluasi essay berjumlah 10 butir soal untuk mengetahui kemampuan siswa dalam materi manusia dan manfaatnya.

\section{Hasil belajar IPA siswa siklus II}

Tabel 4.7 hasil belajar IPA siklus II

\begin{tabular}{lcccc}
\hline No & Nilai & kategori & Frekuensi & Peresentase \\
\hline 1. & $0-59$ & Sangat Kurang & 0 & $0 \%$ \\
2. & $65-69$ & Kurang & 3 & $12 \%$ \\
3. & $75-79$ & Cukup & 4 & $16 \%$ \\
4. & $85-89$ & Baik & 9 & $32 \%$ \\
5 & $95-100$ & Sangat baik & 10 & $40 \%$ \\
Jumlah & & $\mathbf{2 6}$ & $\mathbf{1 0 0 \%}$ \\
Nilai rata-rata hasil belajar IPA siklus II & $\mathbf{8 4 , 4 \%}$
\end{tabular}

\section{Lampiran 92}

Hasil refleksi dari data observasi menunjukan bahwa, antara nilai siswa pada siklus I dan siklus II mengalami peningkatan. Siswa yang sudah memenuhi KKM dari keseluruhan siswa juga mengalami peningkatan. Pada siklus I ketuntasan siswanya hanya mencapai 15 dengan persentase $60 \%$ dan nilai rata-rata siswa yaitu $66,6 \%$ sedangkan pada siklus II mencapai 21 dengan persentase $84 \%$ dan nilai rata-rata siswa yaitu $84,4 \%$. Hasil ini sudah sangat memenuhi kriteria keberhasilan penelitian, sehingga tidak dilanjutkan pada siklus berikutnya.

Berdasarkan tabel diatas menunjukan bahwa dari 26 siswa terdapat 22 siswa yang tuntas dengan persentase $84 \%$ dengan nilai $75-100$, sedangkan siswa yang tidak tuntas dalam pembelajaran ada 4 siswa dengan persentase 16\% dengan nilai 0-79, maka ketuntasan hasil belajar sudah memenuhi kriteria ketuntasan minimal (KKM) sebesar 70 dengan persentase 80\% dari keseluruhan jumlah siswa maka dianggap tuntas secara keseluruhan.

Hasil refleksi dari data observasi menunjukan bahwa pembelajaran siklus I belum maksimal dalam proses pembelajaran. Secara umum, pelaksanaan tindakan pada siklus II tidak ditemukan kendala yang cukup serius karena siklus II merupakan upaya perbaikan dari siklus I yang telah direncanakan.

Pada dasarnya metode resitasi mampu meningkatkan hasil belajar siswa, dapat meningkatkan rasa ingin tahu siswa dan meningkatkan kemandirian siswa kelas V SD Inpres Borong Jambu II. Hal ini dapat dilihat berdasarkan hasil tes siklus I dari 26 siswa dan hanya 16 siswa yang mencapai KKM 75 dan yang tidak memenuhi KKM yaitu 10 siswa, sedangkan pada siklus II, dari 26 siswa yang mengikuti tes, 23 siswa sudah memenuhi nilai KKM yaitu 75, sedangkan 3 siswa yang mengikuti tes belum memenuhi nilai KKM yang telah ditentukan. Berdasarkan kriteria keberhasilan yang telah ditetapkan, maka dapat dikatakan bahwa keberhasilan proses belajar dengan menggunakan metode resitasi sudah terlaksana dengan karakteristiknyadan keberhasilan dari jumlah siswa yang mengikuti proses belajar mengajar telah mencapai nilai KKM 75 keatas, dengan demikian penelitian dihentikan dan tidak dilanjutkan pada siklus selanjutnya. 
Hal ini menunjukan bahwa indikator keberhasilan terpenuhi, dengan demikian penggunaan metode resitasi mampu meningkatkan hasil belajar siswa, khususnya mata pelajaran IPA pada siswa kelas V SD Inpres Borong Jambu II Kota Makassar.

\section{Pembahasan}

Penelitian ini dilakukan pada dua siklus, pada setiap siklus terdapat 3x pertemuan. Adapun yang dilakukan pada siklus I dan II untuk meningkatkan hasil belajar IPA dengan menggunakan metode resitasi pada kelas V SD Inpres Borong Jambu II Kota Makassar.

Dalam penerapan metode resitasi di siklus I dan siklus II dapat meningkatkan hasil belajar siswa khususnya pada mata pelajaran IPA pada kelas SD Inpres Borong Jambu II. Dari hasil siklus I nilai rata-rata siswa $66,6 \%$ dan meningkat menjadi $84,4 \%$ pada siklus II.

Metode resitasi merupakan metode pembelajaran yang dapat menghidupkan suasana kelas menjadi menarik dan aktif. Pada metode resitasi ini juga aktivitas belajar lebih banyak berpusat pada siswa sedangkan guru hanya bertindak sebagai penyampaian informasi, fasilitator, dan pembimbing.

Pada siklus I selama kegiatan pembelajaran berlangsung siswa kurang aktif dan terlibat dalam mengikuti proses pembelajaran, pencapaian indikator keberhasilan dari hasil belajar belum mencapai $80 \%$ siswa yang memperoleh nilai KKM 75 belum dianggap tuntas secara klasikal. Setelah diakan refleksi kegiatan pada siklus I , maka peneliti melakukan beberapa perbaikan pada siklus II dengan kegiatan yang dianggap perlu, seperti lebih memaksimalkan penggunaan metode pembelajaran yang digunakan dan guru lebih menyiapkan diri agar penampilan dan penyampaian materi dalam pembelajaran dapat lebih maksimal, sehingga siswa akan lebih muda menerima materi dan merasa antusias dalam mengikuti pembelajaran karena hal ini sangat berpengaruh terhadap meningkatnya hasil belajar siswa.

Siklus II terlihat bahwa hasil belajar IPA pada siswa kelas V SD Inpres Borong Jambu II Kota Makassar terjadi peningkatan hasil belajar siswa, siklus I ke siklus II mengalami peningkatan. Dari data di atas dapat disimpulkan bahwa, nilai siswa pada siklus I mengalami peningkatan. Persentase ketuntasan siswa yang sudah memenuhi KKM dari keseluruhan siswa juga mengalami peningkatan. Dari 26 jumlah siswa pada siklus I ketuntasan siswanya hanya 16 siswa dengan persentase $60 \%$ dan nilai rata-ratanya $66,6 \%$ sedangkan pada siklus II mencapai 23 siswa dengan persentase $84 \%$ dan nilai rata-rata 84,4\%. Hal ini menunjukan bahwa indicator keberhasilan terpenuhi, dengan demikian penggunaan metode resitasi mampu meningkatkan hasil belajar siswa, khususnya mata pelajaran IPA pada siswa kelas V SD Inpres Borong Jambu II Kota Makassar.

\section{SIMPULAN DAN SARAN}

Berdasarkan hasil penelitian tindakan kelas (PTK) yang telah dilaksanakan di SD Inpres Borong Jambu II Kota Makassar tentang penerapan metode resitasi maka, dapat disimpulkan sebagai berikut:

1. Penerapan metode resitasi dalam peningkatan hasil belajar IPA dan kemapuan berfikir kritis siswa dalam proses pembelajaran.

2. Penerapan metode resitasi dapat meningkatkan hasil belajar IPA hal ini dapat dilihat dari kondisi awal rata-rata sebelum dan sesudah melakukan penelitian disiklus I menggunakan metode resitasi mendapatkan presentasi ketuntasan siswa mencapai $(66,6 \%)$ kemudian dilanjutkan ke siklus II dengan penerapan metode resitasi, hasil 
belajar siswa mengalami peningkatan. Pada siklus II rata-rata meningkat menjadi $(83,4 \%)$ pada siklus II.

Upaya yang dilakukan peneliti dalam meningkatkan hasil belajar adalah dengan mengikuti langkah-langkah pelaksanaan metode resitasi. Dalam meningkatkan hasil belajar IPA dari siklus I ke siklus II, dilakukan dengan berbagai perbaikan. Setelah dilakukan upaya perbaikan, pada siklus II kriteria keberhasilan sudah tercapai sehingga siklus dihentikan.

\section{DAFTAR RUJUKAN}

Adah Isti'Noorlaila Feida. 2020. Teori-Teori Belajar Dalam Pendidikan. Tasikmalaya Jawa Barat: Edu Publisher.

Aidil Erawan. 2020. Peningkatan prestasi belajar melalui metode rsitasi. Madiun: CV. Bayfa Cendekia Indonesia.

Anggraini Ayu. 2019. Upaya Meningkatkan Hasil Belajar Matematika Menggunakan Model Course Review Horay (Crh) Dengan Strategi Afektif Pada Siswa Kelas III Sd Negeri 74 Bonti-Bonti Kota Maros.Skripsi, FKIP, Universitas Megarezky, Makassar.

Astawan Gede I \& I Gusti Ayu Tri Agustiana. 2020. Pendidikan IPA Sekolah Dasar di Era Revolusi Industri 4.0. Bandung: Nilacakra

Bellona Mardatillah Sabillah. 2017. Meningkatkan hasil belajar matematika pada pengelohan data dengan menerapkan metode reciprocal teaching murid kelas VI SD centre bottoe kecamatan tanete rilau kabupaten barru. Makassar. Volume (2) : 73-85.

Bhidju Hariyanto Roni. 2020. Peningkatan Hasil Belajar IPA Melaui Metode Demonstrasi. Kota Malang: CV. Multimedia Edukasi.

Felma Cahyani Sombou. 2018. Penerapan Strategi Everyone Is A Teacher Here Dalam Meningkatkan Minat Belajar IPA Pada Siswa Kelas V SD Inpres Perumnas Antang II/I Kecamatan Manggala Kota Makassar. Skripsi, FKIP, Universitas Megarezky, Makassar.

Hafera Darmawan \& Murnihati Sarumaha. 2020. Teori Pengenalan Ilmu Pengetahuan Alam Pada Anak Usia Dini. Yogyakarta: Penerbit Embrio

Herlynda Syopyan. 2015. Peningkatan Hasil Belajar Ipa Siswa Kelas V Melalui Metode Resitasi Di Sd Al Azhar Syifa Budi Jakarta Selatan. Jakarta. Volume 6 (1) : 134144.

Jusmawati Dan Eka fitriana HS. 2019. Keefektifan Model Pembelajaran Kooperatif Tipe Think Pair Share (TPS) Dalam Pembelajaran Matematika Siswa Kalas V SD Negri Panaikang 1 Kota Makassar: Socioedu Journal ( Pendidikan, Sosial, Humaniora). 
Nursia. 2018. Peningkatan Belajar IPA Melalui Model Pembelajaran Pair Check Pada Siswa Kelas III SD Inpres Balngkala III Kecamatan Manggala Kota Makassar. Skripsi, FKIP, Universitas Megarezky, Makassar.

Perawati, dkk. 2018. Pengaruh Lingkungan Sosial Dan Motivasi Terhadap Hasil Belajar IPS Siswa SD Inpres Perumnas Antang Kecamatan Manggala Kota Makassar. Makassar. Volume 3 (2) : 76-84.

Sukardi. 2013. Metode Penelitian Pendidikan Tindakan Kelas Implementasi dan Pengembang annya. Jakarta: PT Bumi Karsa.

Sugiyono. 2013. Metode Penelitian Kuantitatif Kuatitatif dan R\&D. Bandung: Alfabeta

Undang-Undang RI No. 20 Tahun 2003 Tentang Sistem Pendidikan Nasional. Jakarta: Depdiknas

Wedywati Nelly \& Yasinta Lisa. 2019. Pembelajaran IPA di Sekolah Dasar. Yogyakarta: Penerbit DEEPUBLISH

Jusmawati, J., Satriawati, S., Akhiruddin, A., Rahman, A., Arsyad, N., \& Irman, R. (2021). Mengembangkan perangkat pembelajaran matematika berbasis model creative problem solving di sekolah dasar. Tinjauan Linguistik dan Budaya , 5 (1), 406-421. 